\title{
Modulation of the Surface-layer Protein of Clostridium difficile through Cwp84 Inhibition
}

\author{
Major D. Gooyit and Kim D. Janda* \\ Departments of Chemistry and Immunology and Microbial Science, The Skaggs Institute for Chemical \\ Biology, and The Worm Institute of Research and Medicine, The Scripps Research Institute, 10550 North \\ Torrey Pines Road, La Jolla, California 92037, United States
}

*Email: kdjanda@scripps.edu

Table of Contents

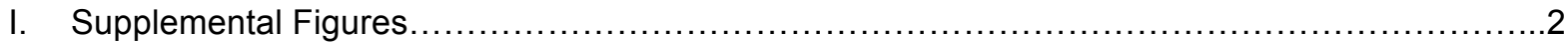

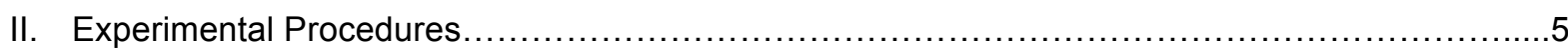

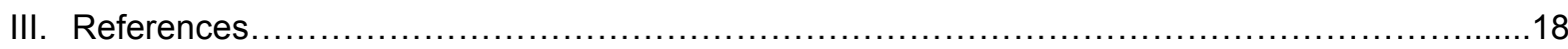




\section{Supplemental Figures}

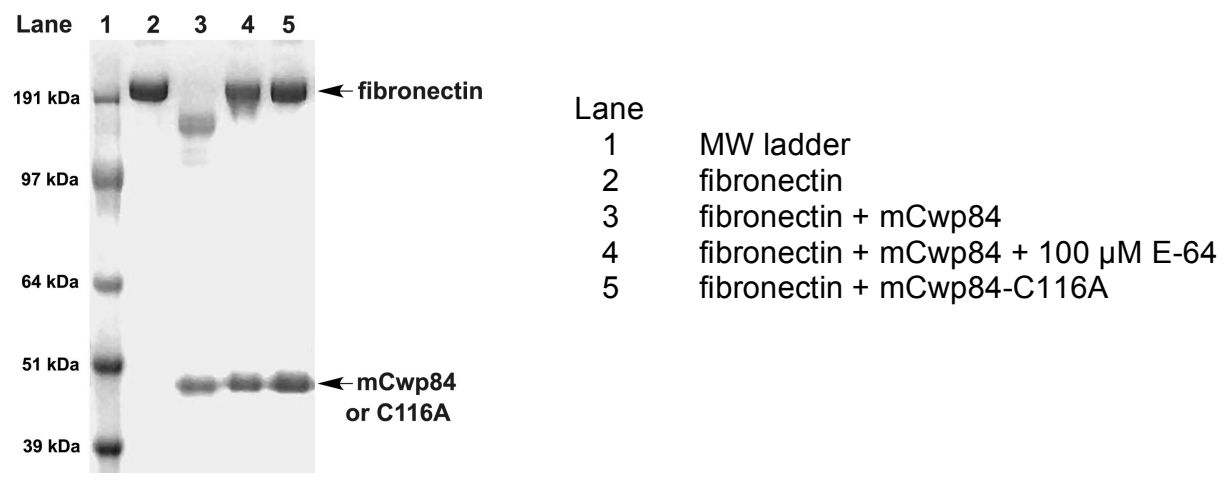

Figure S1. mCwp84-catalyzed cleavage of fibronectin. SDS-PAGE image following an 18-h incubation at 37 ${ }^{\circ} \mathrm{C}$. Condition: $1 \mu \mathrm{g} \mathrm{mCwp84}$ or C116A, $5 \mu \mathrm{g}$ fibronectin, $2 \mathrm{mM}$ DTT, with or without E-64, in PBS pH 7.4

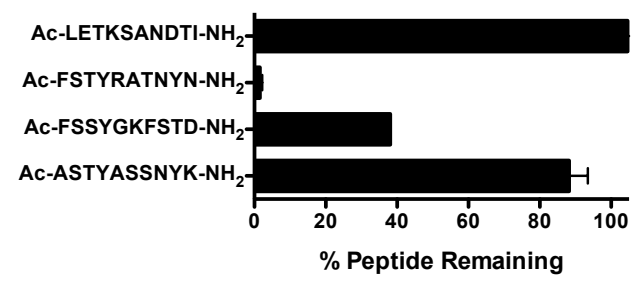

Figure S2. mCwp84-catalyzed cleavage of decapeptides. Data shown as percent decapeptide remaining \pm s.d. $(n=2)$ following incubation of the decapeptide $(20 \mu \mathrm{M})$ with $30 \mathrm{nM}$ mCwp84, $2 \mathrm{mM}$ DTT in PBS pH 7.4, for $18 \mathrm{~h}$ at $37^{\circ} \mathrm{C}$, as assessed by LC/MS.

${ }^{* * *}$ Note that under this reaction condition, no cleavage of Ac-LETKSANDTI-NH $\mathrm{H}_{2}$ was observed after the overnight incubation. At a higher concentration of $\mathrm{mCwp} 84(300 \mathrm{nM})$, the decapeptide was processed up to $31 \%$. 
A
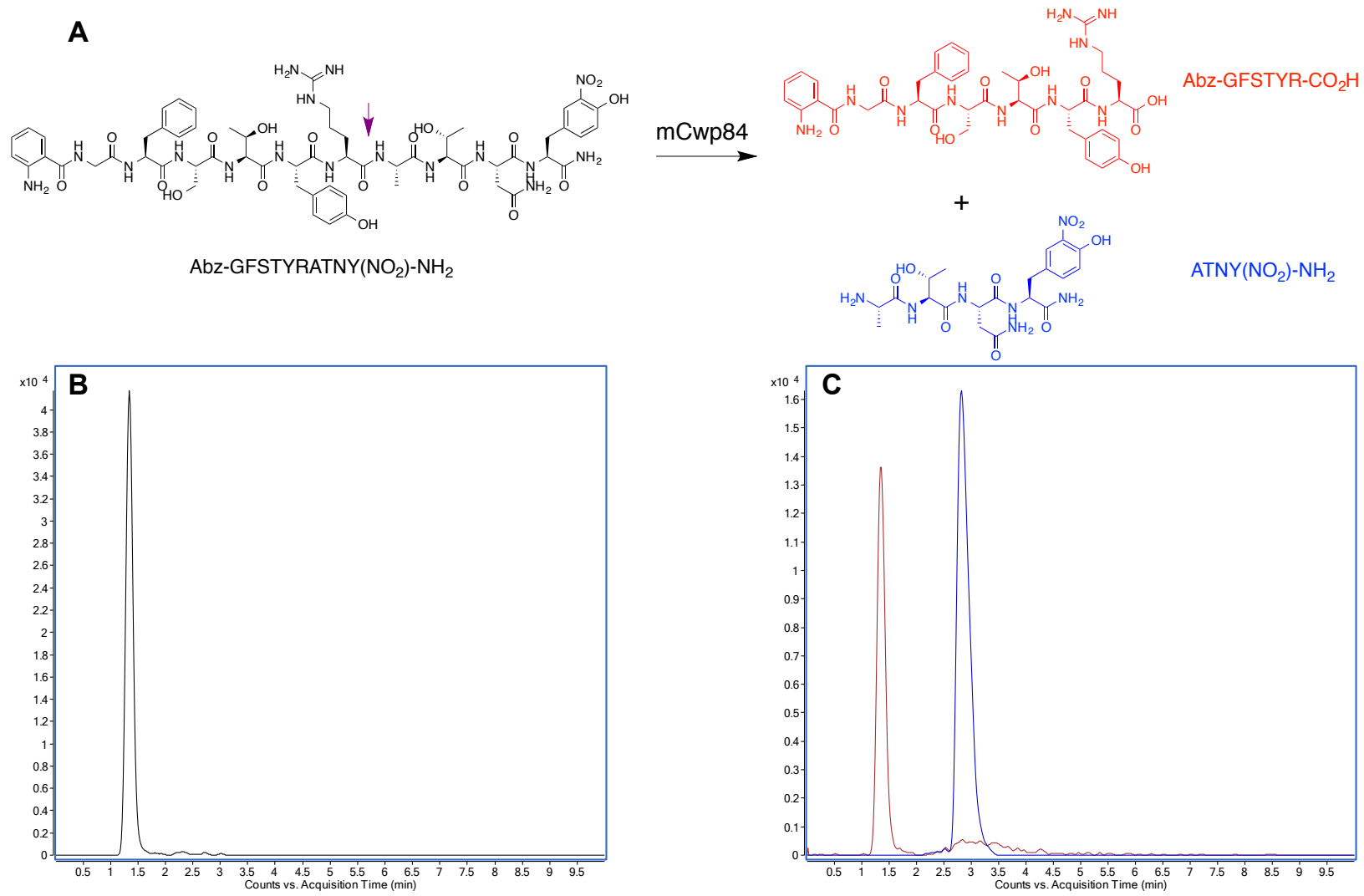

Figure S3. mCwp84-catalyzed cleavage of Abz-GFSTYRATNY $\left(\mathrm{NO}_{2}\right)-\mathrm{NH}_{2}$. A) Reaction scheme of the cleavage of Abz-GFSTYRATNY $\left(\mathrm{NO}_{2}\right)-\mathrm{NH}_{2}$. B) control Abz-GFSTYRATNY $\left(\mathrm{NO}_{2}\right)-\mathrm{NH}_{2}$, extracted ion chromatogram (EIC) at $\mathrm{m} / \mathrm{z}=671.791$ atomic mass unit (a.m.u.), $[\mathrm{M}+2 \mathrm{H}]^{2+}$. C) Reaction condition: $20 \mu \mathrm{M}$ FRET substrate, $30 \mathrm{nM}$ mCwp84, $2 \mathrm{mM}$ DTT in PBS pH 7.4, 3-h incubation at $37^{\circ} \mathrm{C}$. Superimposed EICs (of the cleavage products) at $\mathrm{m} / \mathrm{z}=425.186$ a.m.u. for Abz-GFSTYR- $\mathrm{CO}_{2} \mathrm{H},[\mathrm{M}+2 \mathrm{H}]^{2+}$ (shown in red), and at $m / z=512.776$ a.m.u. for $\operatorname{ATNY}\left(\mathrm{NO}_{2}\right)-\mathrm{NH}_{2},[\mathrm{M}+\mathrm{H}]^{+}$(shown in blue).
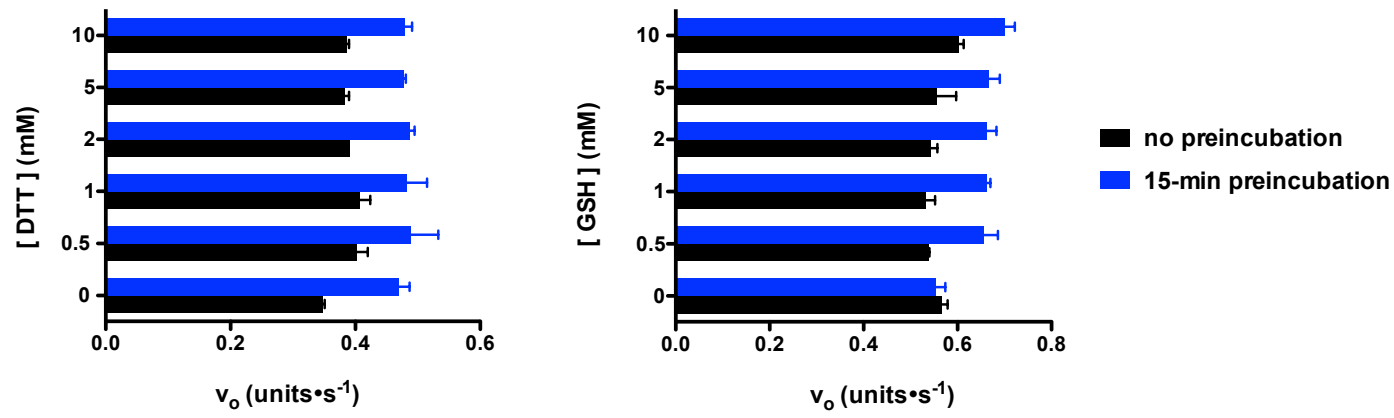

Figure S4. Effect of reducing agent on mCwp84 activity. Condition: $30 \mathrm{nM} \mathrm{mCwp} 84$ (with or without incubation with reducing agent prior to addition of substrate), $20 \mu \mathrm{M}$ Abz-GFSTYRATNY $\left(\mathrm{NO}_{2}\right)-\mathrm{NH}_{2}$ in PBS $\mathrm{pH} 7.4$ at $37^{\circ} \mathrm{C}$. Data shown as mean velocity (expressed in fluorescence units/sec) $\pm \mathrm{s} . \mathrm{d}$. $(\mathrm{n}=2)$. 

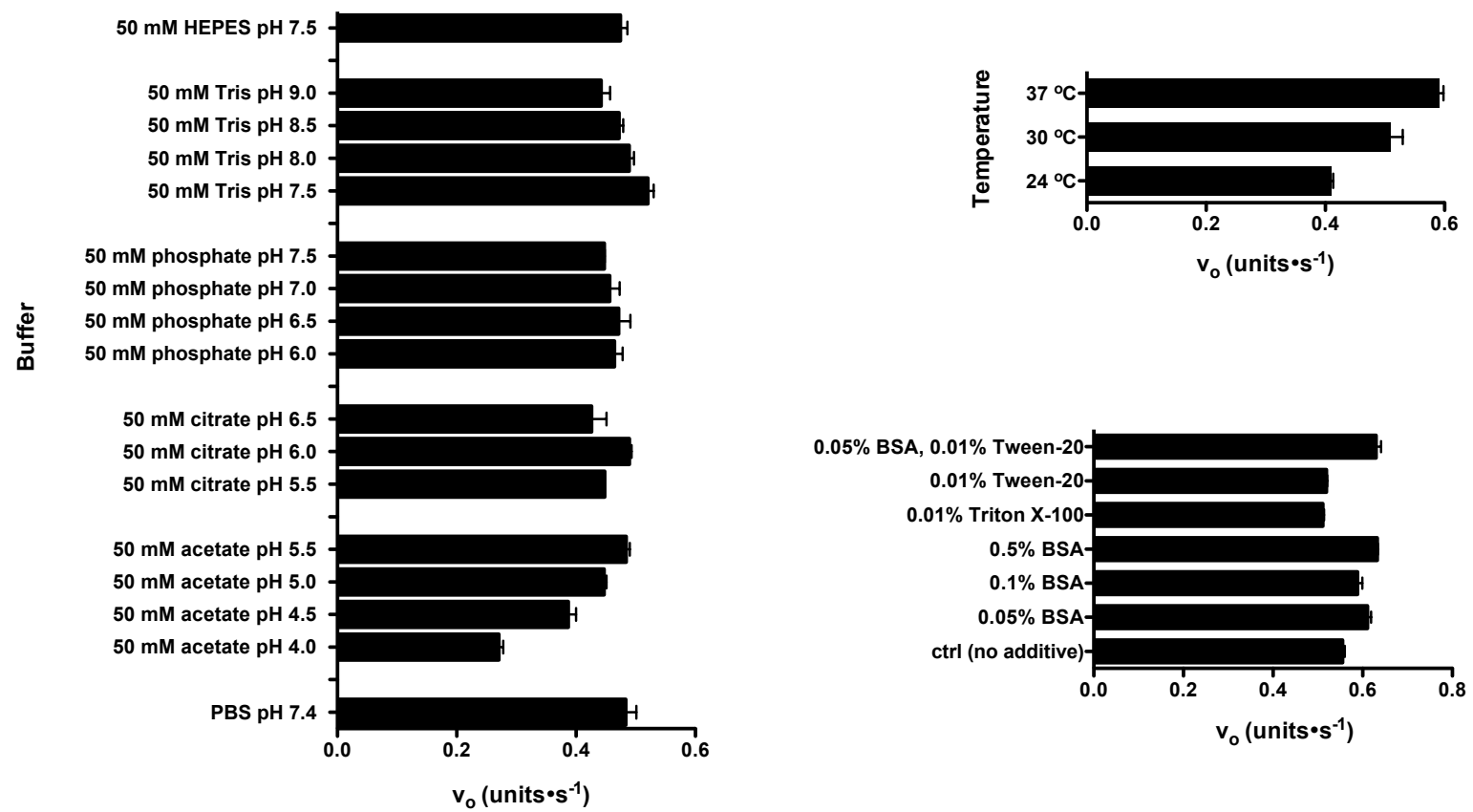

Figure S5. Effects of buffer/pH, temperature and additives on mCwp84 activity. Condition: $30 \mathrm{nM}$ mCwp84, $20 \mu \mathrm{M}$ Abz-GFSTYRATNY $\left(\mathrm{NO}_{2}\right)-\mathrm{NH}_{2}$ in PBS pH 7.4 at $37^{\circ} \mathrm{C}$. Data shown as mean velocity (expressed in fluorescence units/sec) \pm s.d., $(n=2)$.

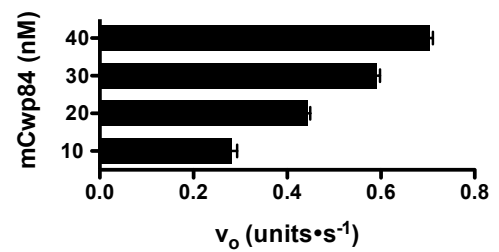

Figure S6. Activity at varying mCwp84 concentration. Condition: $20 \mu \mathrm{M}$ Abz-GFSTYRATNY $\left(\mathrm{NO}_{2}\right)-\mathrm{NH}_{2}$ in PBS pH 7.4, 0.05\% BSA, $0.01 \%$ Tween-20, $2 \mathrm{mM} \mathrm{GSH}$ at $37^{\circ} \mathrm{C}$. Data shown as mean velocity (expressed in fluorescence units/sec $) \pm$ s.d. $(n=2)$

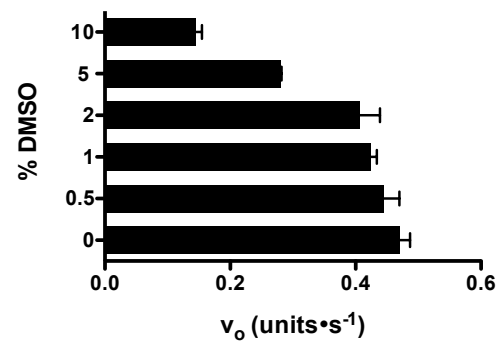

Figure S7. Effect of DMSO on mCwp84 activity. Condition: $20 \mathrm{nM}$ Cwp84, $20 \mu \mathrm{M}$ Abz-GFSTYRATNY $\left(\mathrm{NO}_{2}\right)$ $\mathrm{NH}_{2}$ in PBS pH 7.4, 0.05\% BSA, $0.01 \%$ Tween-20, $2 \mathrm{mM} \mathrm{GSH}$ at $37{ }^{\circ} \mathrm{C}$. Data shown as mean velocity (expressed in fluorescence units/sec) \pm s.d. $(n=2)$. 


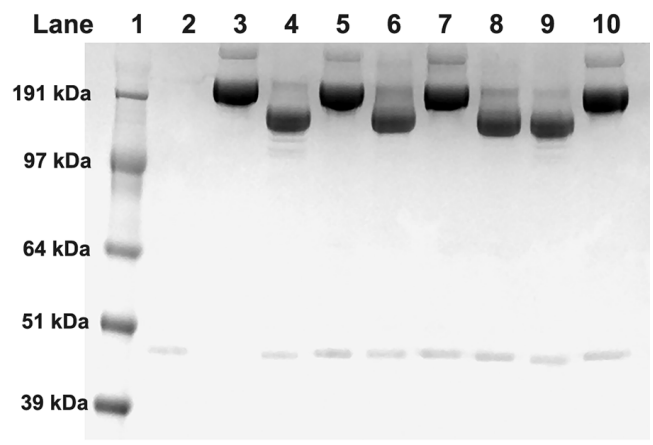

MW ladder

mCwp84

fibronectin

fibronectin + mCwp84

fibronectin + mCwp84 + $50 \mu \mathrm{M}$ E-64

fibronectin + mCwp84 $+50 \mu \mathrm{M} 8 \mathbf{b}$

fibronectin + mCwp84 + $50 \mu \mathrm{M} 8 \mathrm{c}$

fibronectin + mCwp84 + $5 \mu \mathrm{M}$ E-64

fibronectin + mCwp84 $+5 \mu \mathrm{M} 8 \mathrm{~b}$

fibronectin + mCwp84 $+5 \mu \mathrm{M} 8 \mathrm{c}$

Figure S8. Inhibition of fibronectin cleavage. SDS-PAGE image following an 18-h incubation of $5 \mu \mathrm{g}$ fibronectin with $0.50 \mu \mathrm{g} \mathrm{mCwp84,} 2 \mathrm{mM}$ DTT and inhibitors (E-64, 8b or 8c) in PBS pH 7.4 at $37^{\circ} \mathrm{C}$.

\begin{tabular}{|c|c|c|c|c|c|c|c|c|}
\hline & \multirow[b]{2}{*}{1} & \multirow{3}{*}{2} & \multirow[b]{2}{*}{3} & \multirow[b]{2}{*}{4} & \multirow[b]{2}{*}{5} & \multicolumn{2}{|r|}{ Lane } & \multirow{5}{*}{$\begin{array}{l}\text { DMSO control } \\
5 \mu \mathrm{M} \mathrm{E}-64 \\
50 \mu \mathrm{M} \text { E-64 } \\
5 \mu \mathrm{M} \text { 8b } \\
50\end{array}$} \\
\hline & & & & & & & 1 & \\
\hline & & & & & & & 3 & \\
\hline & & & - & & & SlpA & 4 & \\
\hline & & & & & & & 5 & \\
\hline
\end{tabular}

Figure S9. Surface-layer processing in Clostridium difficile. C. difficile 630 was grown anaerobically in the presence of E-64 and $\mathbf{8 b}$ at $37{ }^{\circ} \mathrm{C}$ for $18 \mathrm{~h}$. Cells were harvested and analyzed by SDS-PAGE/Western blotting using anti-LMW SIp.

\section{Experimental Procedures}

\section{A. Biochemical Assays}

\section{Preparation of the Vector Encoding Cwp84 $30-517$}

Genomic DNA from Clostridium difficile (Hall and O'Toole) Prevot (ATCC ${ }^{\circledR}$ BAA-1382- $5^{\mathrm{TM}}$ ) was used as the template for cloning. PCR was performed using the following oligonucleotide primers: cwp84-f, 5TAAGccatggCAGAAAACCATAAAACTCTAGATGG-3' (Ncol restriction site shown in lowercase letters) and cwp84-r, 5'-AGGctcgagAACTGCTGTTTCATATCTATCTGCAG-3' (Xhol restriction site shown in lowercase letters). Double digest reaction mixtures using both restriction endonucleases $\mathrm{Ncol}$ and Xhol were carried out on both the gel-purified PCR product and the empty pET-28b(+) vector. The purified DNA fragments were ligated using T4 DNA ligase (Invitrogen) to generate the construct $p E T-28 b(+)-$ cwp84, which contains a hexahistidine $\left(\mathrm{His}_{6}\right)$ tag at the $\mathrm{C}$-terminus. The nucleotide sequence of $\mathrm{pET}$ $28 \mathrm{~b}(+)$-cwp84 was verified by standard sequencing analysis.

\section{Overexpression of $\mathrm{Cwp}_{8} 4_{30-517}-\mathrm{His}_{6}$}

The pET-28b(+)-cwp84 expression vector was transformed in E. coli BL21 (DE3) (Invitrogen). Cells were grown in LB $(100 \mathrm{~mL})$ supplemented with $50 \mu \mathrm{g} / \mathrm{mL}$ kanamycin at $37^{\circ} \mathrm{C}$ to $\mathrm{OD}_{600}$ of $\sim 0.4$. Expression of Cwp84 $4_{30-517}$ was initiated by addition of IPTG $\left(0.25 \mathrm{mM}\right.$ final concentration) at $37^{\circ} \mathrm{C}$ and the cells were harvested at $3 \mathrm{~h}$ post-induction. Cell lysis and extraction of proteins were done using $\mathrm{B}$ - 
PER® Bacterial Protein Extraction Reagent in phosphate buffer (Pierce). After gentle agitation of the suspension at $4^{\circ} \mathrm{C}$ for $10 \mathrm{~min}$, cell debris from the obtained lysate was removed by centrifugation $\left(13,000 \mathrm{rpm}, 15 \mathrm{~min}, 4^{\circ} \mathrm{C}\right)$. The supernatant was then subjected to affinity chromatography purification using Talon ${ }^{\circledR}$ Metal Affinity Resin (Clontech Laboratories, Inc.), following the manufacturer's standard protocol. Elution of $\mathrm{His}_{6}$-tagged proteins was accomplished using a gradient of imidazole (100 to 500 $\mathrm{mM}$ ). Eluted fractions containing Cwp84 were dialyzed against PBS pH 7.4, aliquoted and stored at -80 ${ }^{\circ} \mathrm{C}$ until use.

\section{Production of $\mathrm{Cwp}_{34} 4_{30-517}-\mathrm{C} 116 \mathrm{~A}-\mathrm{His}_{6}$}

Site-directed mutagenesis of Cwp84 ${ }_{30-517}$ was performed using the $\mathrm{Q}^{\circledR}$ Site-Directed Mutagenesis Kit (New England Biolabs. Inc.), with the following oligonucleotide primers: Cwp84 ${ }_{\mathrm{C} 116 \mathrm{~A}-\mathrm{f}}$, TCTTAATACAGCCTGGTCTTTTTCAGGTATG and Cwp84 ${ }_{\mathrm{C} 116 \mathrm{~A}}{ }^{-r}$, CTTCCTTGATTTTTTGCTGG. The procedures for the overexpression and purification of $\mathrm{Cwp}_{30} 4_{30-517}-\mathrm{C} 116 \mathrm{~A}-\mathrm{His}{ }_{6}$ were the same as described for the wild-type Cwp84.

\section{Fibronectin Cleavage Assay}

Five microgram of fibronectin (Roche) was incubated in $20 \mu \mathrm{L} \mathrm{PBS} \mathrm{pH} 7.4$ containing mCwp84 (0.5 or 1 $\mu \mathrm{g}$ ) and $2 \mathrm{mM}$ DTT, at $37{ }^{\circ} \mathrm{C}$ for $18 \mathrm{~h}$. The reaction was stopped by addition of NuPAGE LDS sample buffer (containing DTT), incubated at $95{ }^{\circ} \mathrm{C}$ for $5 \mathrm{~min}$, and then resolved by SDS-PAGE. Gel images were visualized using FluorChem IS-8900 (Alpha Innotech). Fibronectin cleavage assays were performed in duplicate.

\section{Cleavage of Decapeptides and Fluorogenic Substrates}

Peptide stock solutions $(10 \mathrm{mM})$ were prepared in DMSO, and diluted to appropriate working stock solutions with PBS pH 7.4.

Decapeptides and fluorogenic substrates (at $20 \mu \mathrm{M}$ final concentration) were incubated in $50 \mu \mathrm{L}$ PBS $\mathrm{pH} 7.4$ containing $30 \mathrm{nM} \mathrm{mCwp} 84$ and $2 \mathrm{mM}$ DTT, at $37^{\circ} \mathrm{C}$ for $18 \mathrm{~h}$ or $3 \mathrm{~h}$. The reaction was quenched by addition of $50 \mu \mathrm{L}$ acetonitrile containing $1 \mu \mathrm{M}$ internal standard. The mixture was centrifuged at $13,000 \mathrm{rpm}$ for $10 \mathrm{~min}$ and the supernatant was analyzed by LC/MS. Quantification of remaining peptide was determined using peak area ratios relative to internal standard.

\section{FRET-based Assay for mCwp84 Activity}

a. Determination of $K_{\mathrm{m}}$ and $k_{\text {cat }}$ for Abz-GFSTYRATNY $\left(\mathrm{NO}_{2}\right)-\mathrm{NH}_{2}$.

\begin{tabular}{|c|c|}
\hline Step & Description \\
\hline 1 & $\begin{array}{l}\text { To a 96-well microplate (Corning }{ }^{\circledR} \text { Half Area Black with Clear Flat Bottom Polystyrene } \\
\text { NBS }^{\mathrm{TM}} \text { ), add } 40 \mu \mathrm{L} \text { of assay buffer and } 5 \mu \mathrm{L} \text { of } 200 \mathrm{nM} \mathrm{mCwp} 84 \text { to each well }\end{array}$ \\
\hline 2 & Add $5 \mu \mathrm{L}$ of appropriate FRET substrate working stock concentration \\
\hline 3 & $\begin{array}{l}\text { Measure fluorescence readings at } 37{ }^{\circ} \mathrm{C} \text { on a SpectraMax M2e Microplate Reader } \\
\text { (Molecular Devices) using the following settings: } \\
\lambda_{\mathrm{ex}}=320 \mathrm{~nm} ; \lambda_{\mathrm{em}}=420 \mathrm{~nm} \text {, kinetic setting over } 20 \mathrm{~min} \\
\text { Sensitivity: Readings (20), PMT (medium) }\end{array}$ \\
\hline \multicolumn{2}{|c|}{ Notes } \\
\hline \multicolumn{2}{|r|}{$\begin{array}{l}\text { Assay buffer: PBS pH 7.4, } 0.05 \% \text { BSA, } 0.01 \% \text { Tween-20, } 2 \mathrm{mM} \mathrm{GSH} \text {. } \\
\text { Note: Use freshly prepared GSH (stock solution of } 250 \mathrm{mM} \text { in } \mathrm{H}_{2} \mathrm{O} \text { ) }\end{array}$} \\
\hline \multicolumn{2}{|r|}{$\begin{array}{l}\text { FRET substrate: Abz-GFSTYRATNY }\left(\mathrm{NO}_{2}\right)-\mathrm{NH}_{2} \text { stock solution (10 mM in DMSO) diluted to working } \\
\text { stock concentrations with PBS } \mathrm{pH} 7.4\end{array}$} \\
\hline
\end{tabular}


b. Inhibitor screening and $\mathrm{IC}_{50}$ determination

\begin{tabular}{|c|c|}
\hline Step & Description \\
\hline 1 & $\begin{array}{l}\text { To a 96-well microplate, add } 35 \mu \mathrm{L} \text { of assay buffer, } 5 \mu \mathrm{L} \text { of } 200 \mathrm{nM} \text { mCwp84 and } 5 \mu \mathrm{L} \text { of } \\
\text { appropriate inhibitor working stock concentration. }\end{array}$ \\
\hline 2 & Seal plate with a sealing film (Platemax ${ }^{1 \mathrm{M}}$ Axyseal, Axygen) \\
\hline 3 & Incubate the sealed plate at $37^{\circ} \mathrm{C}$ for $30 \mathrm{~min}$. \\
\hline 4 & Add $5 \mu \mathrm{L}$ of $120 \mu \mathrm{M}$ FRET substrate solution to each well (12 $\mu \mathrm{M}$ final concentration) \\
\hline 5 & $\begin{array}{l}\text { Measure fluorescence readings at } 37{ }^{\circ} \mathrm{C} \text { on a SpectraMax M2e Microplate Reader } \\
\text { (Molecular Devices) using the following settings: } \\
\lambda_{\text {ex }}=320 \mathrm{~nm} ; \lambda_{\text {em }}=420 \mathrm{~nm} \text {, kinetic setting over } 10 \mathrm{~min} \\
\text { Sensitivity: Readings (20), PMT (medium) }\end{array}$ \\
\hline Note & \\
\hline
\end{tabular}

c. Determination of $K_{\mathrm{l}}$ and $k_{\text {inact }}$ for the inhibition of mCwp84 by $8 \mathrm{c}$

The same procedure (as in Inhibitor screening/l $\mathrm{C}_{50}$ determination) was used except that mCwp84 and different concentrations of $8 \mathrm{c}(0$ to $4 \mu \mathrm{M})$ were pre-incubated at various time points, prior to addition of the FRET substrate. For each inhibitor concentration, the natural log of the percentage remaining activity was plotted against pre-incubation time, from which the slope was determined (designated as $-k_{\text {obs }}$ ). Nonlinear regression analysis of $k_{\text {obs }}$ versus concentration [8c] was performed to determine kinetic parameters $k_{\text {inact }}$ and $K_{1}$ based from the function:

$$
k_{\mathrm{obs}}=\frac{k_{\text {inact }} \times[\mathrm{I}]}{K_{\mathrm{I}}+[\mathrm{I}]}
$$

where [l] is the concentration of $\mathbf{8 c}, k_{\text {obs }}$ is the inactivation rate constant for a given [l], $k_{\text {inact }}$ is the maximal inactivation rate constant, and $K_{\mathrm{l}}$ is the inhibitor concentration when the inactivation rate contant is half $k_{\text {inact. }}$.

Kinetic data were analyzed using GraphPad Prism version 5.0b for Mac OS X (GraphPad Software, Inc.).

\section{Surface-layer Processing in Clostridium difficile}

C. difficile 630 (ATCC $®$ BAA $-1382^{\mathrm{TM}}$ ) was routinely cultured either on blood agar base II plates with $5 \%$ sheep blood (Teknova) or in brain-heart infusion supplemented with $0.5 \%$ yeast extract (BHIS) containing $0.03 \%$ L-cysteine. Bacterial culture was performed in an anaerobic cabinet (Coy Lab Products) at $37{ }^{\circ} \mathrm{C}$ in a reducing anaerobic atmosphere $\left(8 \% \mathrm{H}_{2}, 8 \% \mathrm{CO}_{2}, 84 \% \mathrm{~N}_{2}\right)$.

The procedure for the SIpA cleavage and inhibition assay was adapted from Dang et al. ${ }^{1}$ with minor modifications. Briefly, a single colony of $C$. difficile 630 was inoculated into $10-\mathrm{mL}$ BHIS medium and incubated anaerobically for $30 \mathrm{~min}$. Two-mL aliquots of the bacterial culture were then grown in the presence of inhibitor (E-64, 8b and $\mathbf{8 c}$ ) or DMSO control for $18 \mathrm{~h}$. Cells were harvested after centrifugation $(5,000 \mathrm{rpm}, 10 \mathrm{~min})$ at $4{ }^{\circ} \mathrm{C}$, and the culture media $(\mathrm{CM})$ were set aside for analysis. Cell pellets were washed once with PBS and resuspended in $500 \mu \mathrm{L}$ of PBS pH 7.4. NuPAGE LDS sample buffer (containing DTT) were then added to both $\mathrm{CM}$ and the cell suspension and the resulting mixtures were incubated at $95^{\circ} \mathrm{C}$ for $5 \mathrm{~min}$, and thereafter analyzed by SDS-PAGE and Western blotting.

Antibody to C. difficile $630 \mathrm{LMW}-\mathrm{SIp}$ was raised in rabbits against purified LMW-His (prepared as $^{2}$ described previously) ${ }^{2}$ and used at a dilution of 1:500 in 5\% skim milk in TBST. Detection was by enhanced chemiluminescence (SuperSignal ${ }^{\top \mathrm{M}}$ West Dura Extended Duration Substrate, ThermoFisher Scientific) using 1:10,000 dilution of the HRP-conjugated goat anti-rabbit $\lg (\mathrm{H}+\mathrm{L}$, Jackson ImmunoResearch Laboratories, Inc.). Western blots were visualized using FluorChem IS-8900 (Alpha Innotech). 
B. Liquid Chromatography/Mass Spectrometry

1. LC/MS conditions used for quantitation of mCwp84-catalyzed cleavage of decapeptides and fluorogenic substrates

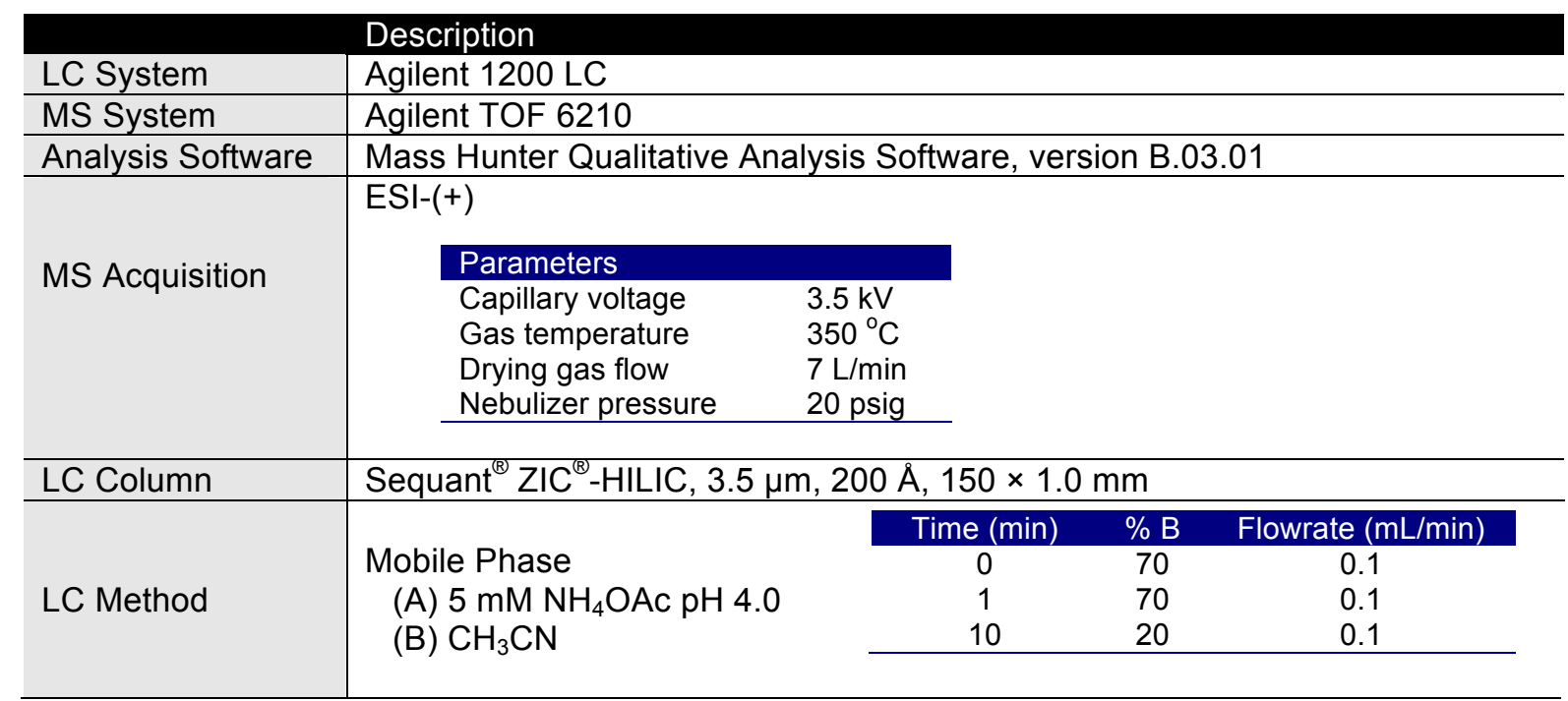

2.LC/MS conditions used for characterization of peptides

\begin{tabular}{|c|c|c|c|c|c|}
\hline & \multicolumn{5}{|l|}{ Description } \\
\hline LC System & \multicolumn{5}{|c|}{ Agilent 1100 Series } \\
\hline MS System & \multicolumn{5}{|c|}{ G6100 Series Single Quadrupole LC/MSD } \\
\hline Analysis Software & \multicolumn{5}{|c|}{ LC/MSD Chemstation, Rev.B.04.03 } \\
\hline \multirow{6}{*}{ MS Acquisition } & \multicolumn{5}{|c|}{ ESI-(+) } \\
\hline & \multicolumn{5}{|l|}{ Parameters } \\
\hline & \multicolumn{5}{|l|}{ Capillary voltage } \\
\hline & Gas temperature & \\
\hline & Drying gas flow & \multirow{2}{*}{\multicolumn{4}{|c|}{$\begin{array}{l}12 \mathrm{~L} / \mathrm{min} \\
35 \mathrm{psig}\end{array}$}} \\
\hline & Nebulizer pressure & & & & \\
\hline LC Column & \multicolumn{5}{|c|}{ Agilent Zorbax 300SB-C8, $5 \mu \mathrm{m}, 4.6 \times 50 \mathrm{~mm}$} \\
\hline \multirow{3}{*}{ LC Method } & \multirow{3}{*}{\multicolumn{2}{|c|}{$\begin{array}{l}\text { Mobile Phase } \\
\text { (A) } 0.1 \% \text { formic acid in } \mathrm{H}_{2} \mathrm{O} \\
\text { (B) } 0.1 \% \text { formic acid in } \mathrm{CH}_{3} \mathrm{CN}\end{array}$}} & Time (min) & $\% \mathrm{~B}$ & Flowrate (mL/min) \\
\hline & & & 0 & 15 & 0.5 \\
\hline & & & $\begin{array}{l}5 \\
8\end{array}$ & $\begin{array}{l}95 \\
95\end{array}$ & $\begin{array}{l}0.5 \\
0.5\end{array}$ \\
\hline
\end{tabular}




\section{Synthesis and Characterization of Compounds}

Rink amide resin (Chem-Impex Int'l. Inc.), backbone amide linker (BAL) resin (Advanced Chemtech), $N$ - $\alpha$ Fmoc-protected amino acids (Novabiochem, Combi-Blocks, or Advanced Chemtech), monoethyl fumarate (Sigma-Aldrich) were used as received. (2S,3S)-3-(ethoxycarbonyl)oxirane-2-carboxylic acid (used for the synthesis of $\mathbf{8 c}$ ) was synthesized according to published procedures. ${ }^{1}$

All compounds were prepared by standard Fmoc-based solid-phase peptide synthesis using either a rink amide linker or BAL. ${ }^{3}$ Cleavage from the resin and deprotection of peptides were achieved in TFA- $\mathrm{H}_{2} \mathrm{O}-$ TIPS (95:2.5:2.5) after stirring for up to $3 \mathrm{~h}$. Following filtration, mixtures were concentrated and the peptides were precipitated and washed several times with diethyl ether.

${ }^{1} \mathrm{H}$ and ${ }^{13} \mathrm{C}$ NMR spectra were recorded on Bruker DRX-600 equipped with a $5 \mathrm{~mm} \mathrm{DCH}$ cryoprobe. All peptides were characterized by LC/MS. The LC/MS traces for the decapeptides, fluorogenic substrates and compounds 5-8 are shown below.

\section{NMR characterization of optimized inhibitors $\mathbf{8 a - c}$}

Ethyl $\quad(E)-4-\left(\left((S)-1-\left(\left((S)-1-\left(\left(\left[1,1^{\prime}-\right.\right.\right.\right.\right.\right.\right.$-biphenyl]-4-ylmethyl)amino)-3-(4-chlorophenyl)-1-oxopropan-2yl)amino)-5-guanidino-1-oxopentan-2-yl)amino)-4-oxobut-2-enoate (8a). ${ }^{1} \mathrm{H}$ NMR $\left(600 \mathrm{MHz}\right.$, DMSO-d $\left.d_{6}\right) \delta$ $1.22(\mathrm{t}, J=7.1 \mathrm{~Hz}, 2 \mathrm{H}), 1.37-1.47(\mathrm{~m}, 2 \mathrm{H}), 1.49-1.57(\mathrm{~m}, 2 \mathrm{H}), 1.63-1.70(\mathrm{~m}, 1 \mathrm{H}), 2.94(\mathrm{dd}, J=9.6$, $13.5 \mathrm{~Hz}, 1 \mathrm{H}), 3.00-3.10(\mathrm{~m}, 3 \mathrm{H}), 4.13-4.19(\mathrm{~m}, 2 \mathrm{H}), 4.21-4.27(\mathrm{~m}, 1 \mathrm{H}), 4.31-4.38(\mathrm{~m}, 2 \mathrm{H}), 4.49$ $(\mathrm{td}, J=6.1,8.8 \mathrm{~Hz}, 1 \mathrm{H}), 6.56(\mathrm{~d}, J=15.5 \mathrm{~Hz}, 1 \mathrm{H}), 7.14(\mathrm{~d}, J=15.5$ $\mathrm{Hz}, 2 \mathrm{H}), 7.24-7.30(\mathrm{~m}, 6 \mathrm{H}), 7.34-7.38(\mathrm{~m}, 1 \mathrm{H}), 7.47(\mathrm{t}, J=7.7 \mathrm{~Hz}$, $2 \mathrm{H}), 7.56(\mathrm{~d}, J=8.2 \mathrm{~Hz}, 2 \mathrm{H}), 7.62-7.65(\mathrm{~m}, 2 \mathrm{H}), 8.01(\mathrm{~s}, 1 \mathrm{H}), 8.55$ $(\mathrm{d}, J=9.0 \mathrm{~Hz}, 1 \mathrm{H}), 8.65(\mathrm{t}, J=6.1 \mathrm{~Hz}, 1 \mathrm{H}), 8.92(\mathrm{~d}, J=7.8 \mathrm{~Hz}, 1 \mathrm{H})$. ${ }^{{ }^{3} \mathrm{C}} \mathrm{NMR}(151 \mathrm{MHz}$, DMSO) $\delta 14.0,24.5,28.7,36.6,40.1,41.8$, $52.5,54.5,60.6,126.4,126.5,127.3,127.8,127.9,128.7,128.9$, $130.9,131.2,136.8,137.3,138.4,138.6,140.0,156.7,163.0,165.0$, $170.7,170.9$.

Ethyl (E)-4-(((S)-1-(((S)-3-(4-chlorophenyl)-1-((4-(4-methylpiperazin-1-yl)benzyl)amino)-1-oxopropan2-yl)amino)-5-guanidino-1-oxopentan-2-yl)amino)-4-oxobut-2-enoate (8b). ${ }^{1} \mathrm{H}$ NMR $\left(600 \mathrm{MHz}\right.$, DMSO- $\left.d_{6}\right)$ $\delta 1.25(\mathrm{t}, J=7.1 \mathrm{~Hz}, 3 \mathrm{H}), 1.37-1.45(\mathrm{~m}, 2 \mathrm{H}), 1.45-1.53(\mathrm{~m}, 1 \mathrm{H}), 1.60-1.67(\mathrm{~m}, 1 \mathrm{H}), 2.72(\mathrm{~s}, 3 \mathrm{H})$, $2.79-2.85(\mathrm{~m}, 2 \mathrm{H}), 2.96-3.02(\mathrm{~m}, 2 \mathrm{H}), 3.03-3.18(\mathrm{~m}, 7 \mathrm{H}), 4.10(\mathrm{dd}, J=5.5,14.9 \mathrm{~Hz}, 1 \mathrm{H}), 4.17-$ $4.26(\mathrm{~m}, 3 \mathrm{H}), 4.33-4.38(\mathrm{~m}, 1 \mathrm{H}), 4.50(\mathrm{td}, J=5.7,8.6 \mathrm{~Hz}, 1 \mathrm{H})$, $6.58(\mathrm{~d}, J=15.5 \mathrm{~Hz}, 1 \mathrm{H}), 6.91(\mathrm{~d}, J=8.7 \mathrm{~Hz}, 2 \mathrm{H}), 7.04(\mathrm{~d}, J=8.6$ $\mathrm{Hz}, 2 \mathrm{H}), 7.12(\mathrm{~d}, J=15.5 \mathrm{~Hz}, 2 \mathrm{H}), 7.20(\mathrm{~d}, J=8.4 \mathrm{~Hz}, 2 \mathrm{H}), 7.25$ (d, $J=8.4 \mathrm{~Hz}, 2 \mathrm{H}), 7.50(\mathrm{t}, J=5.5 \mathrm{~Hz}, 1 \mathrm{H}), 8.17(\mathrm{~d}, J=8.2 \mathrm{~Hz}, 1 \mathrm{H})$, $8.36(\mathrm{t}, J=5.8 \mathrm{~Hz}, 1 \mathrm{H}), 8.71(\mathrm{~d}, J=7.9 \mathrm{~Hz}, 1 \mathrm{H}) .{ }^{13} \mathrm{C}$ NMR $(151$ $\mathrm{MHz}$, DMSO) $\delta 14.0,24.9,28.9,36.9,40.1,40.3,41.6,46.4,52.5$, $52.8,53.8,60.7,115.8,128.0,128.2,128.7,131.0,131.1,136.5$, $137.2,148.9,156.6,158.1,162.9,165.0,170.2,170.6$.

Ethyl (2S,3S)-3-(((S)-1-(((S)-3-(4-chlorophenyl)-1-((4-(4-methylpiperazin-1-yl)benzyl)amino)-1oxopropan-2-yl)amino)-5-guanidino-1-oxopentan-2-yl)carbamoyl)oxirane-2-carboxylate $(8 \mathrm{c}) .{ }^{1} \mathrm{H}$ NMR $\left(600 \mathrm{MHz}, \mathrm{DMSO}-d_{6}\right) \delta 1.24(\mathrm{t}, J=7.1 \mathrm{~Hz}, 3 \mathrm{H}), 1.35-1.45(\mathrm{~m}, 2 \mathrm{H}), 1.46-1.54(\mathrm{~m}, 1 \mathrm{H}), 1.58-1.67(\mathrm{~m}$, $1 \mathrm{H}), 2.75-2.84(\mathrm{~m}, 4 \mathrm{H}), 2.97(\mathrm{dd}, J=5.5,13.6 \mathrm{~Hz}, 2 \mathrm{H}), 3.03-3.10(\mathrm{~m}, 2 \mathrm{H}), 3.14-3.28(\mathrm{~m}, 4 \mathrm{H}), 3.61$ $(\mathrm{d}, J=1.8 \mathrm{~Hz}, 1 \mathrm{H}), 3.75(\mathrm{~d}, J=1.8 \mathrm{~Hz}, 1 \mathrm{H}), 4.09(\mathrm{dd}, J=5.4,14.9 \mathrm{~Hz}, 1 \mathrm{H}), 4.15-4.27(\mathrm{~m}, 3 \mathrm{H}), 4.32-$ $4.37(\mathrm{~m}, 1 \mathrm{H}), 4.47-4.53(\mathrm{~m}, 1 \mathrm{H}), 6.92(\mathrm{~d}, J=8.7 \mathrm{~Hz}, 2 \mathrm{H}), 7.03(\mathrm{~d}$, $J=8.6 \mathrm{~Hz}, 2 \mathrm{H}), 7.21(\mathrm{~d}, J=8.4 \mathrm{~Hz}, 2 \mathrm{H}), 7.27(\mathrm{~d}, J=8.4 \mathrm{~Hz}, 2 \mathrm{H})$, $7.50(\mathrm{t}, J=5.5 \mathrm{~Hz}, 1 \mathrm{H}), 8.27(\mathrm{~d}, J=8.2 \mathrm{~Hz}, 1 \mathrm{H}), 8.41(\mathrm{t}, J=5.8$ $\mathrm{Hz}, 1 \mathrm{H}), 8.58(\mathrm{~d}, J=8.1 \mathrm{~Hz}, 1 \mathrm{H}) .{ }^{13} \mathrm{C}$ NMR $(151 \mathrm{MHz}, \mathrm{DMSO}) \delta$ $13.9,24.8,29.2,37.1,40.1,40.4,41.5,46.2,51.2,52.2,52.6$, $52.8,53.9,61.6,115.8,127.9,128.1,131.0,131.1,136.5,148.7$, $156.6,158.0,164.8,167.1,170.2,170.4$.

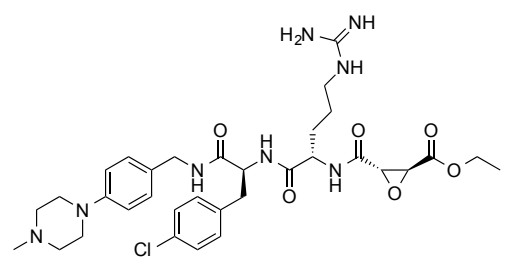




\section{LC/MS characterization}

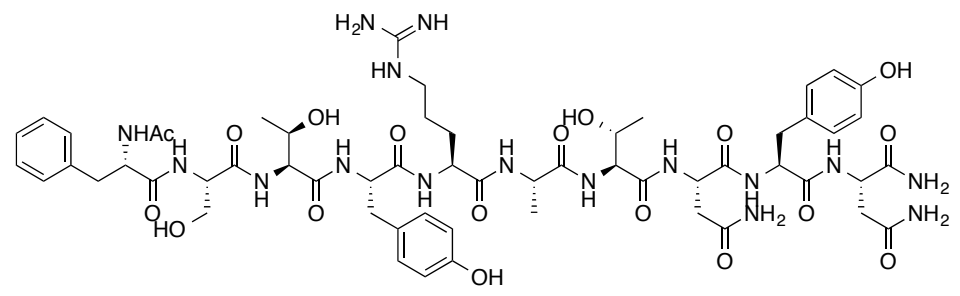

Ac-FSTYRATNYN-NH ${ }_{2}$
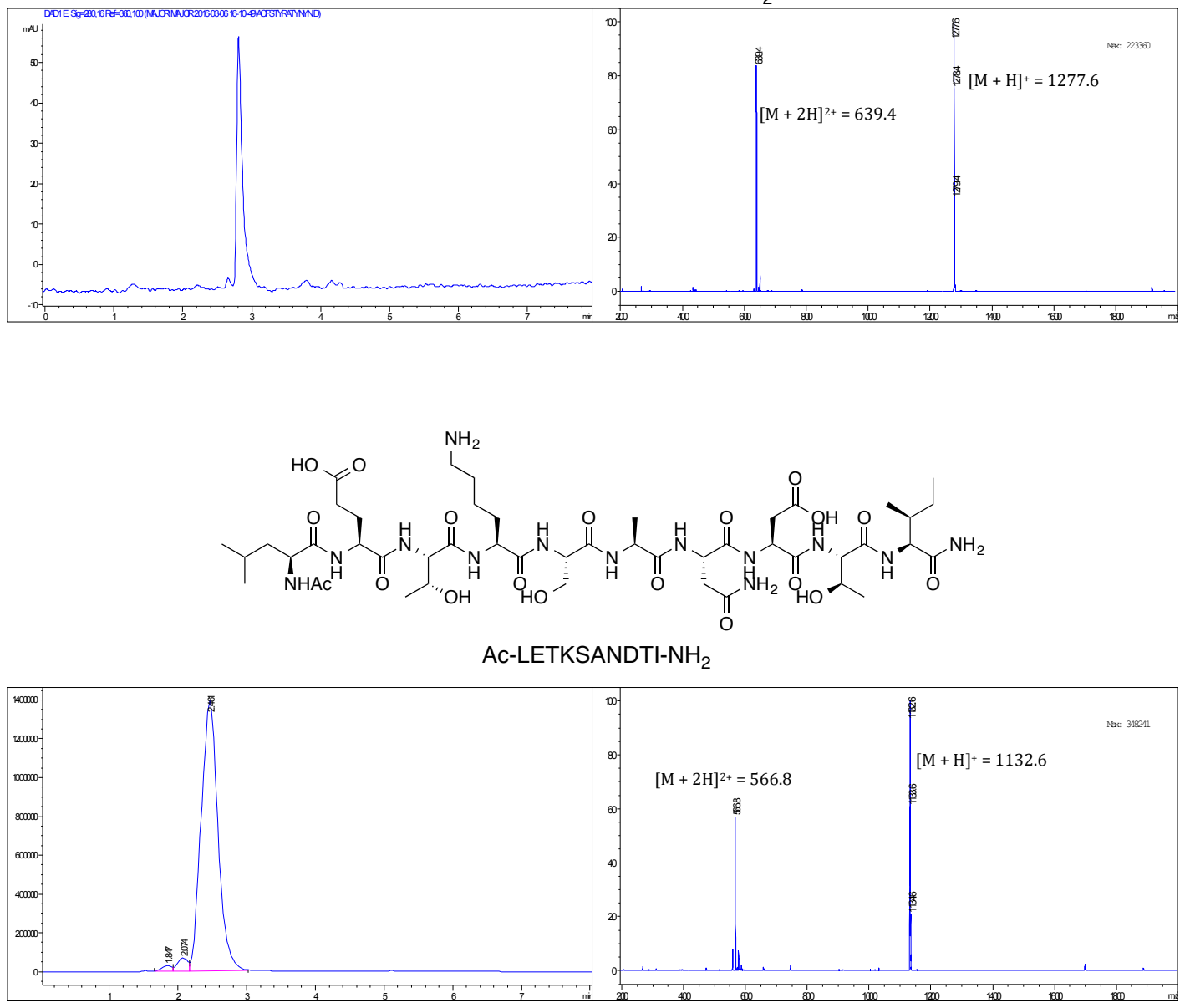


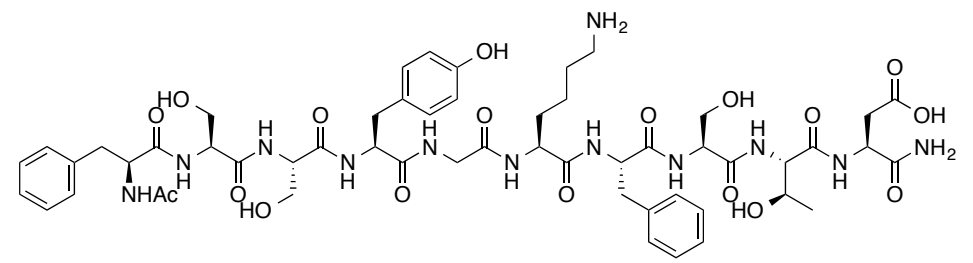

Ac-FSSYGKFSTD-NH ${ }_{2}$
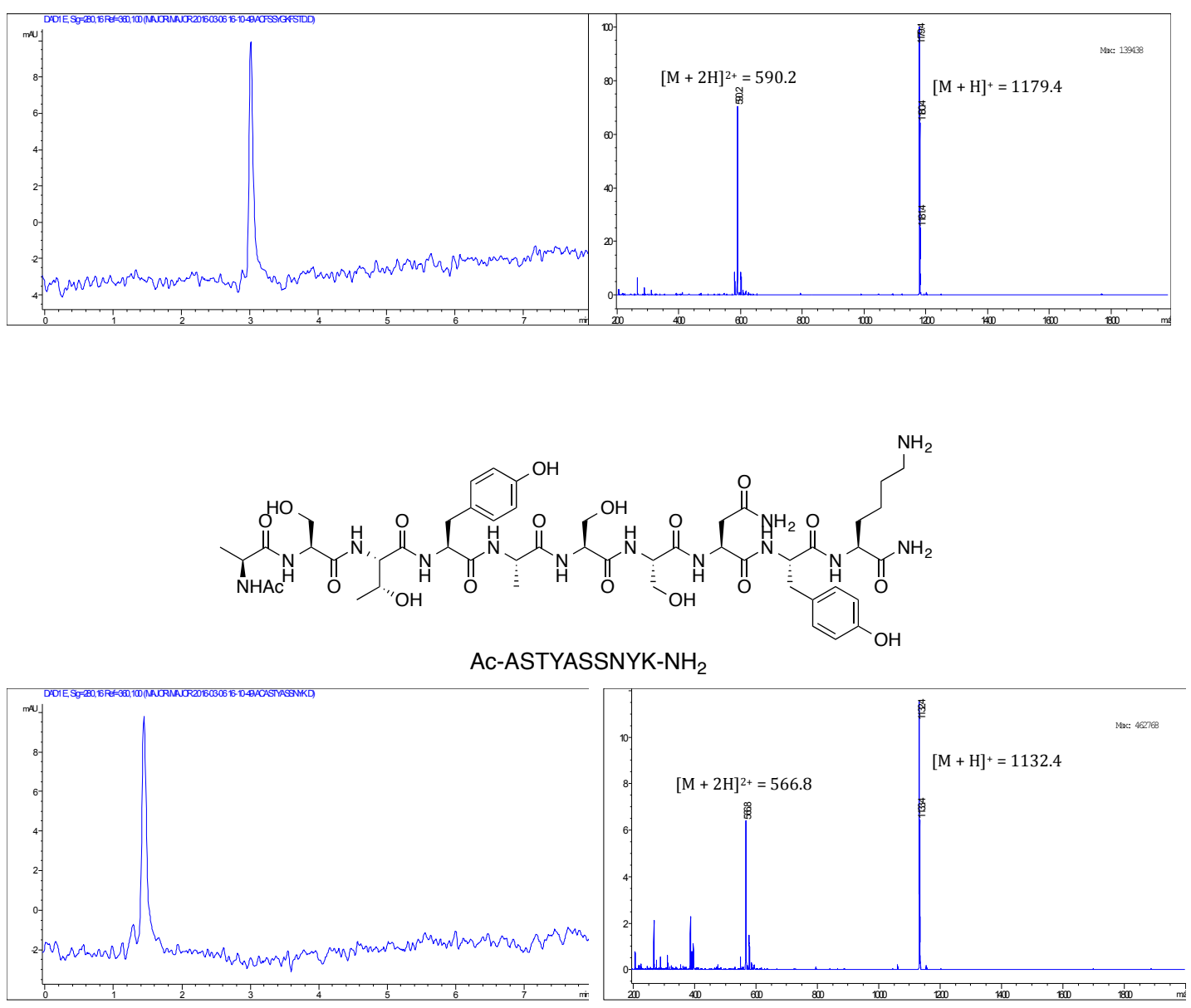


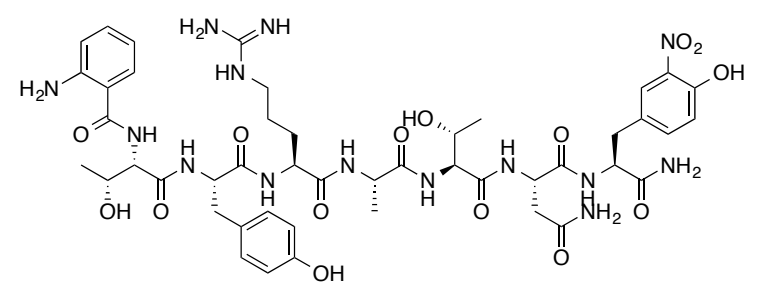

Abz-TYRATNY $\left(\mathrm{NO}_{2}\right)-\mathrm{NH}_{2}$
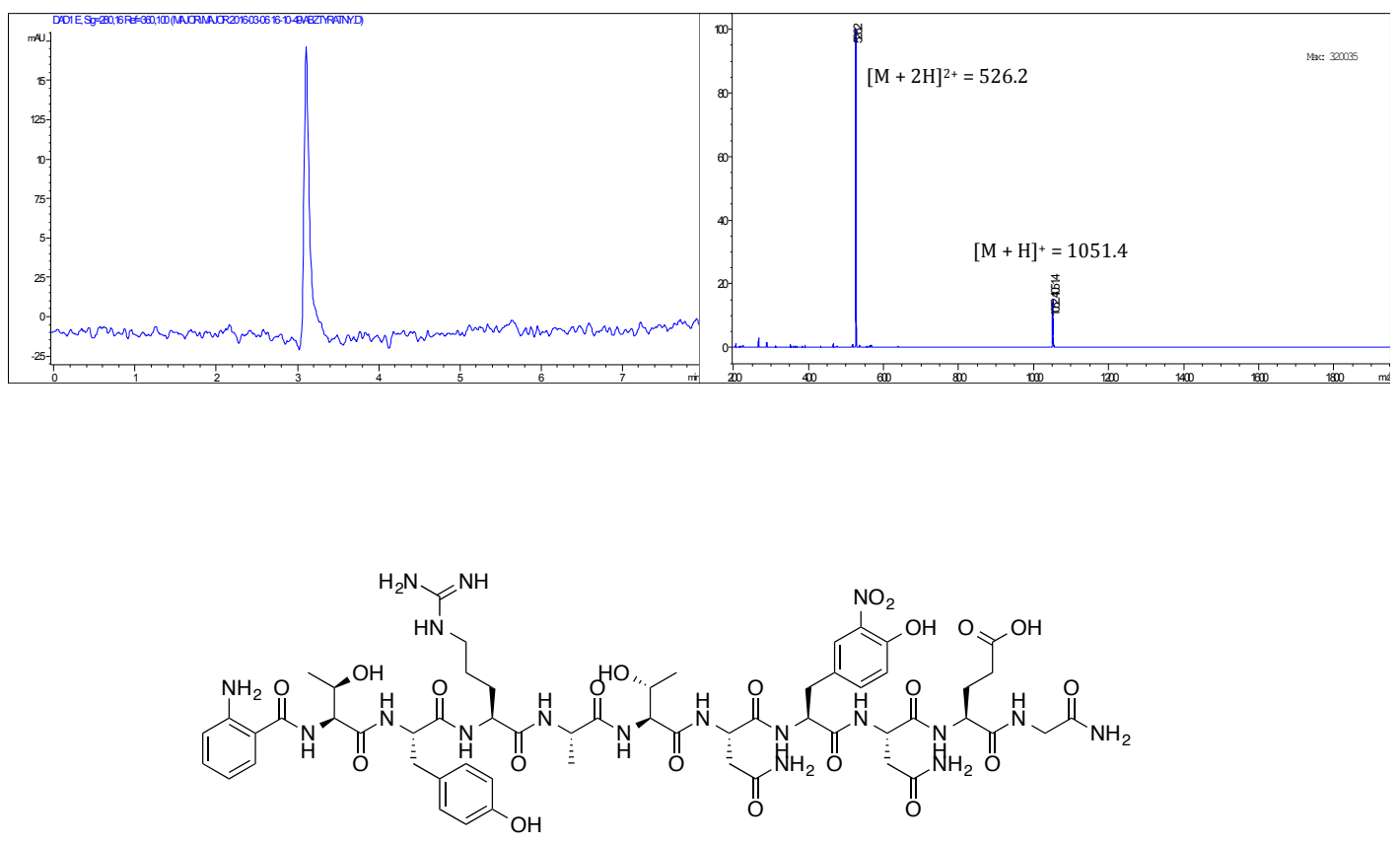

Abz-TYRATNY $\left(\mathrm{NO}_{2}\right) \mathrm{NEG}-\mathrm{NH}_{2}$

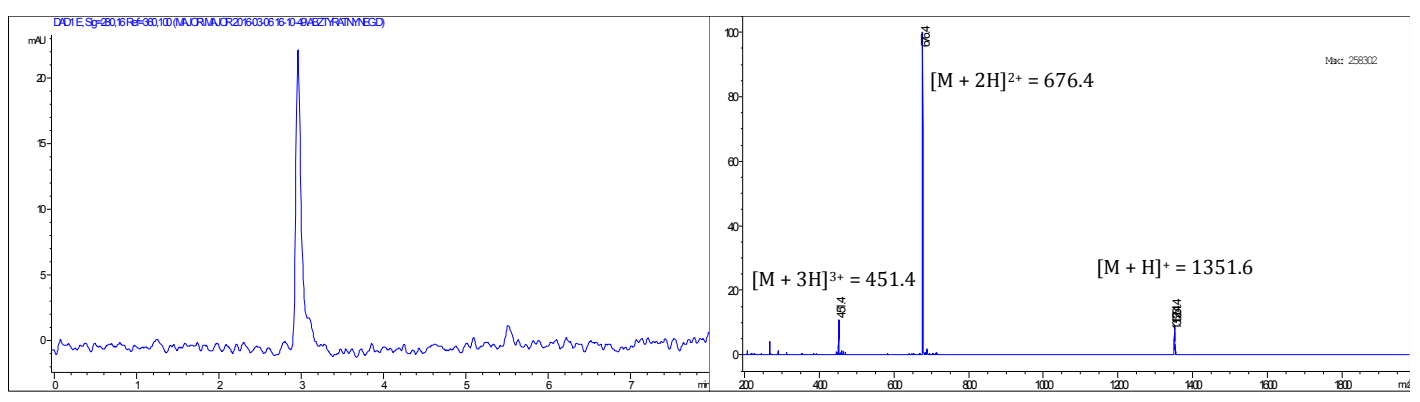




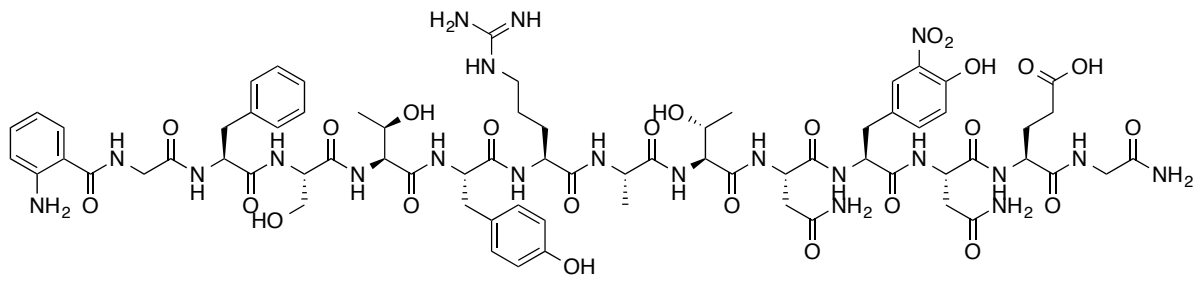

Abz-GFSTYRATNY $\left(\mathrm{NO}_{2}\right) \mathrm{NEG}-\mathrm{NH}_{2}$
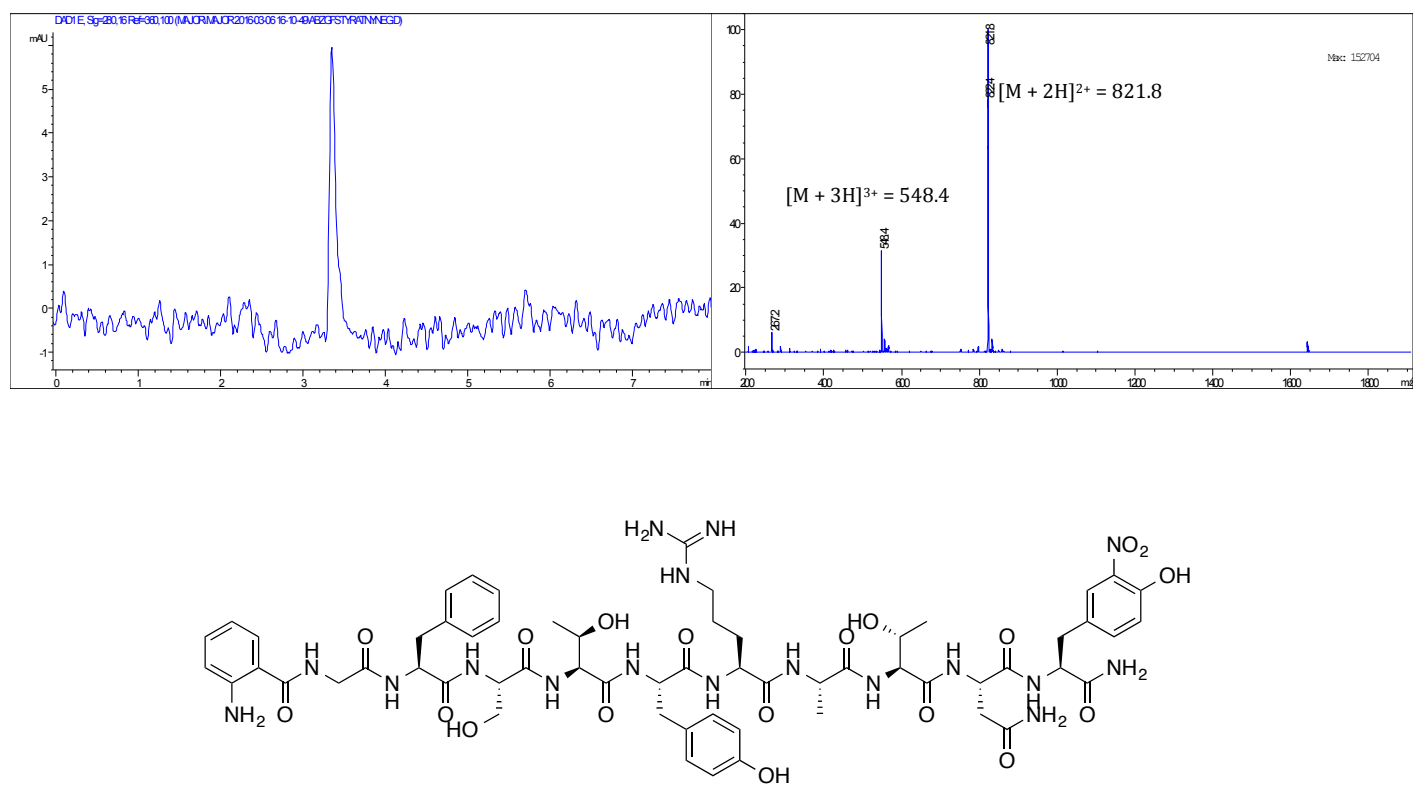

Abz-GFSTYRATNY $\left(\mathrm{NO}_{2}\right)-\mathrm{NH}_{2}$

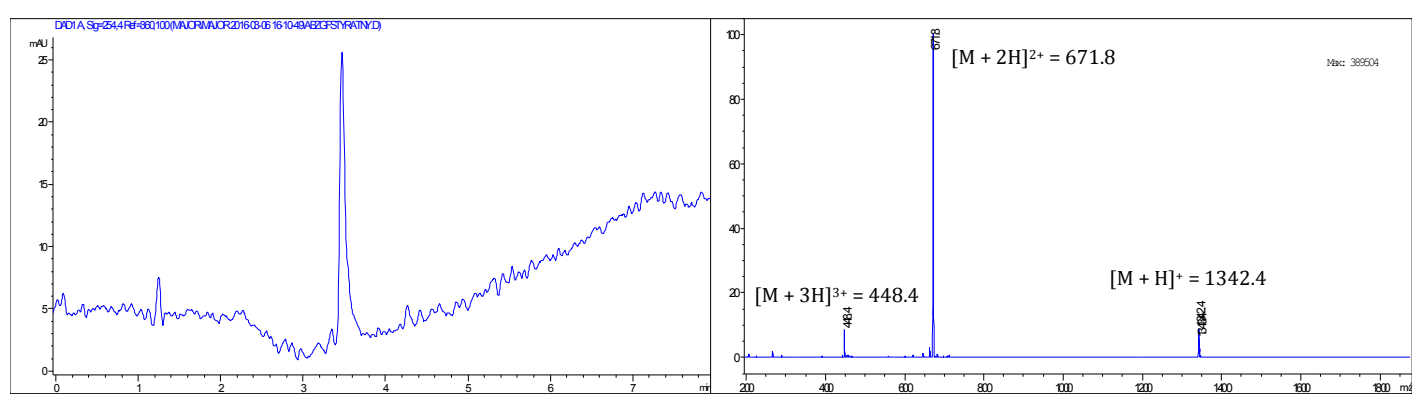



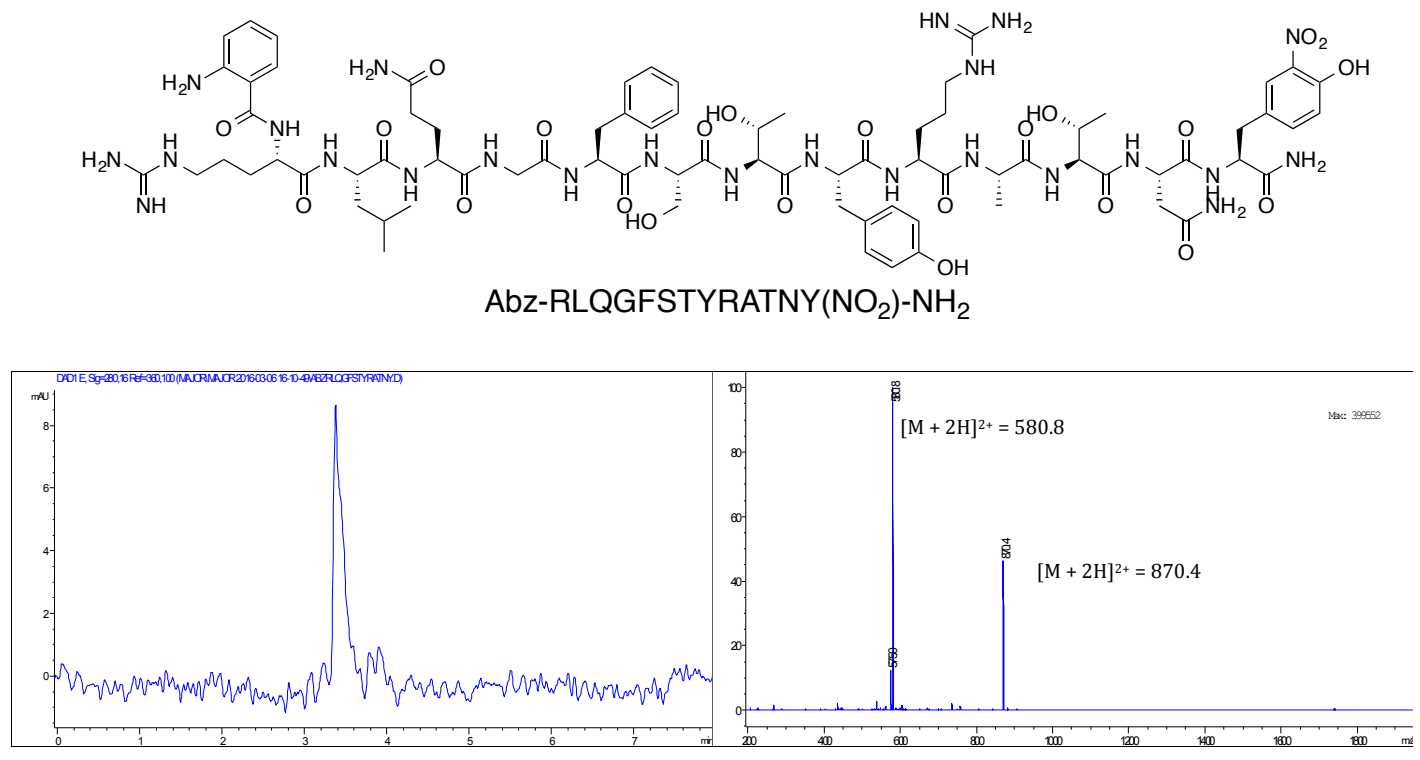

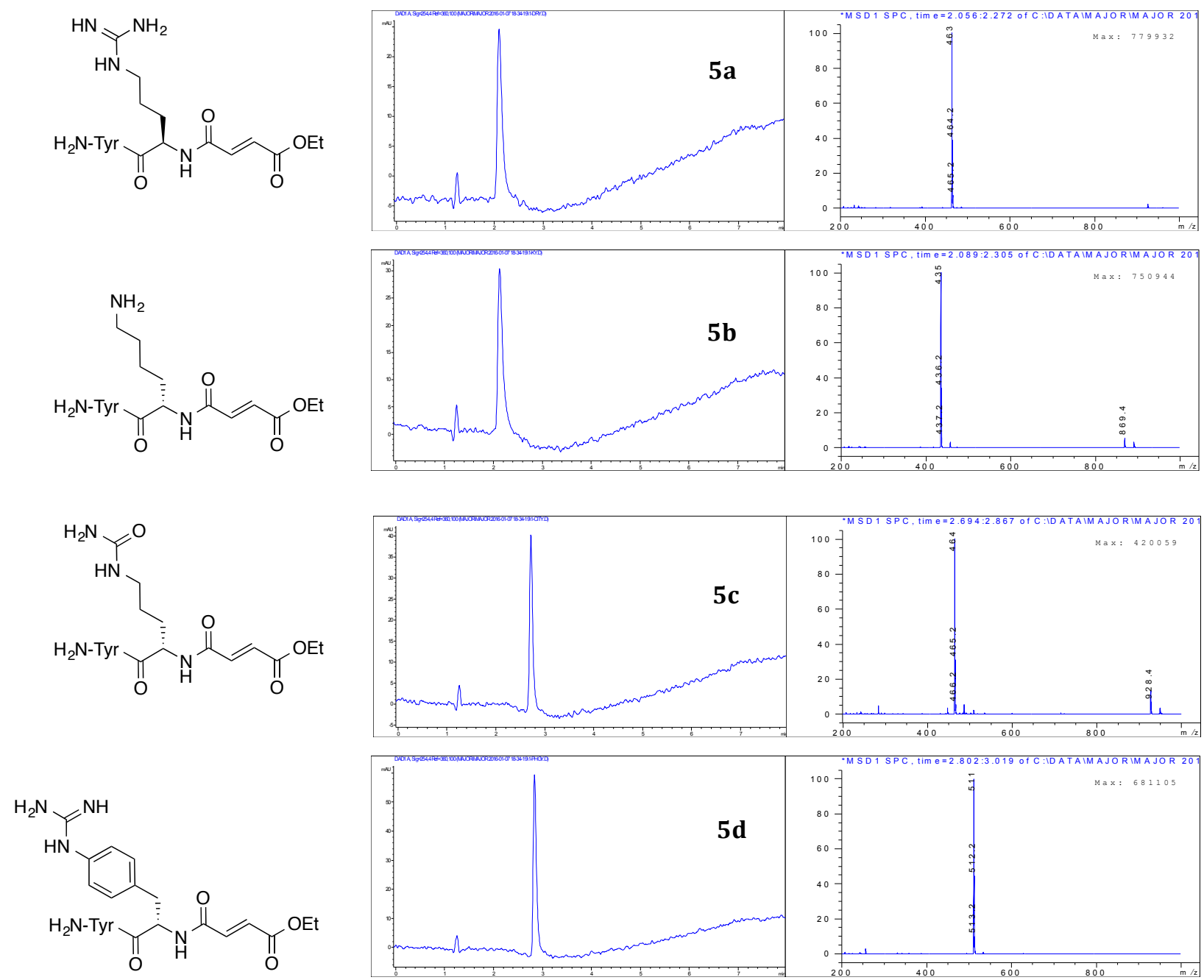
<smiles>CCOC(=O)/C=C/C(=O)[Al]NC(CC(C)C)C(N)=O</smiles><smiles>CCOC(=O)/C=C/C(=O)[Al]NC(Cc1ccccc1)C(N)=O</smiles><smiles>CCOC(=O)/C=C/C(=O)[Al]NC(Cc1ccc(F)cc1)C(N)=O</smiles><smiles>CCOC(=O)/C=C/C(=O)[AlH2]NC(Cc1ccc(Cl)cc1)C(N)=O</smiles>
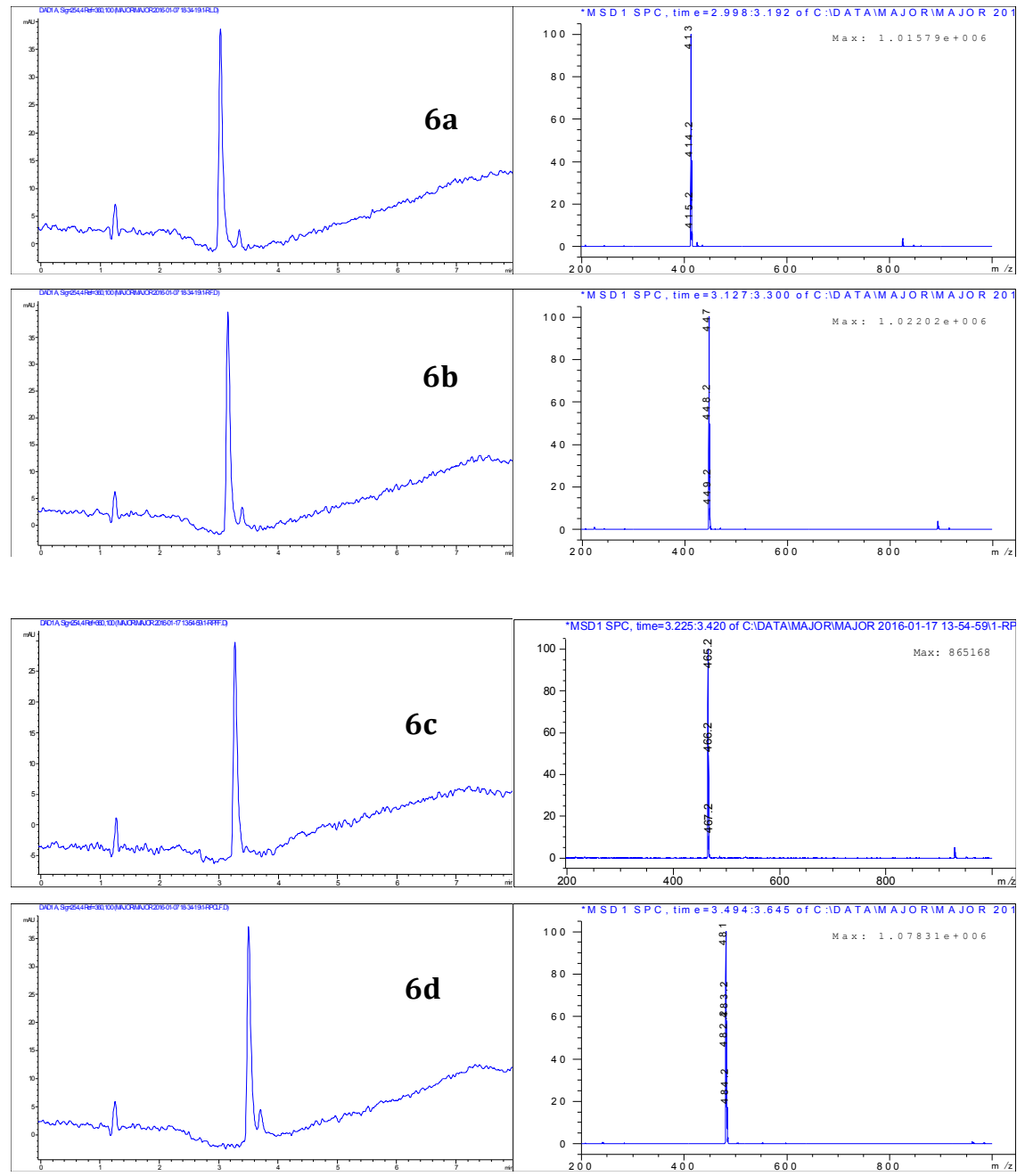


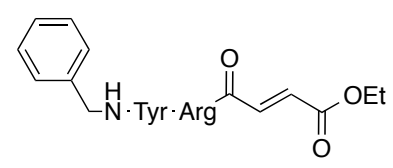

$\mathcal{H}_{\mathrm{H} \cdot \mathrm{Tyr} \cdot \mathrm{Arg}} \stackrel{\mathrm{O}}{\mathrm{O}} \mathrm{OEt}$<smiles>CCOC(=O)/C=C/C(=O)NCCNCc1ccc(Cl)cc1</smiles><smiles>CCOC(=O)/C=C/C(=O)NCc1ccc(Oc2ccccc2)cc1</smiles><smiles>CCOC(=O)/C=C/C(=O)NCCNCc1ccc(-c2ccccc2)cc1</smiles><smiles>CCOC(=O)/C=C/C(=O)NCNCc1ccc(N2CCN(C)CC2)cc1</smiles>
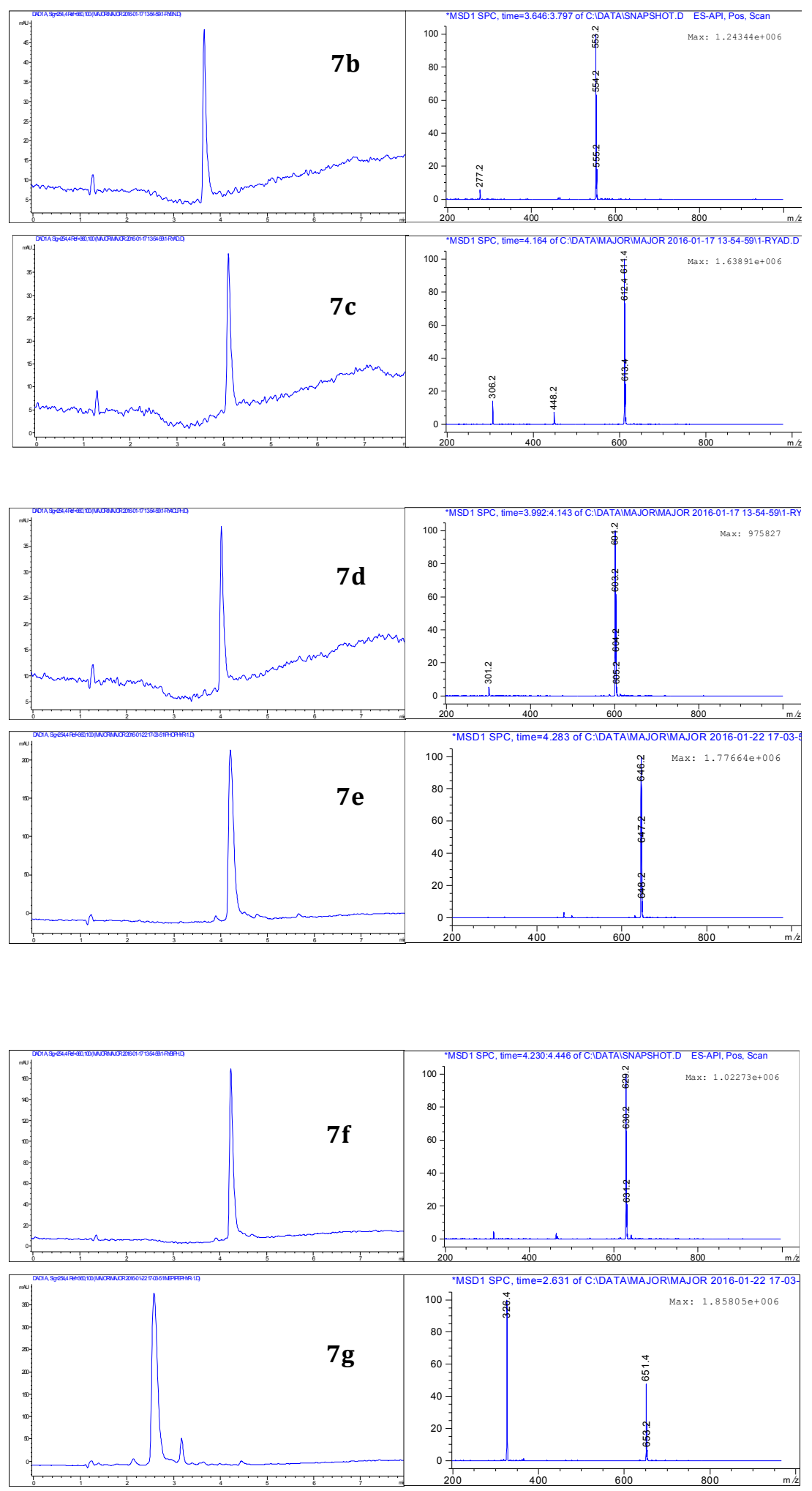

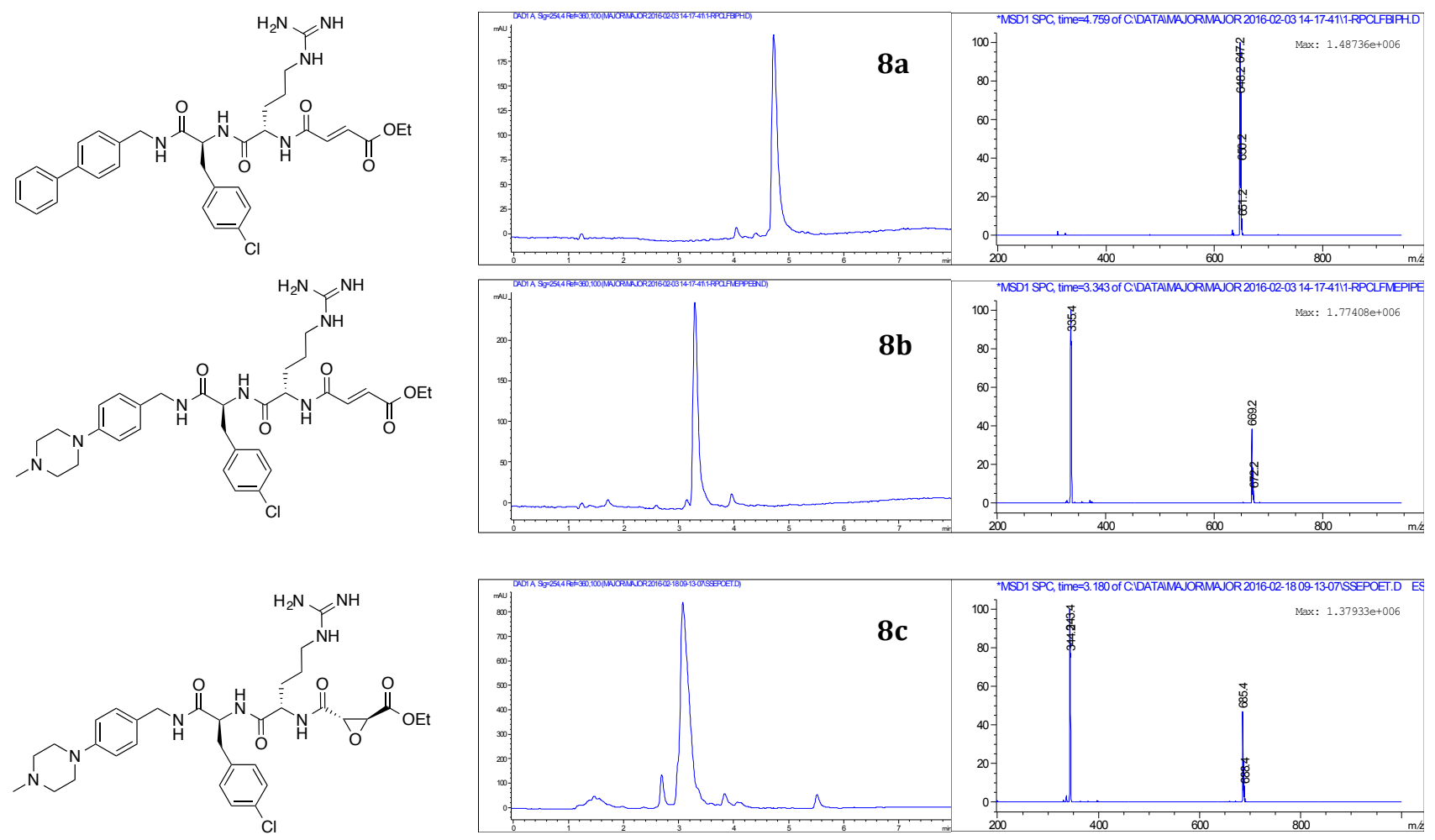

\section{References}

1. Dang, T. H. et al. Chemical probes of surface layer biogenesis in Clostridium difficile. ACS Chem. Biol. 2010, 5, 279-285.

2. Fagan, R. P. et al. Structural insights into the molecular organization of the S-layer from Clostridium difficile. Mol. Microbiol. 2009, 71, 1308-1322.

3. Sadaghiani, A. M. et al.. Solid-phase methods for the preparation of epoxysuccinate-based inhibitors of cysteine proteases. J. Comb. Chem. 2006, 8, 802-804 